\title{
Effect of nocturnal grazing and supplementation on diet selection, eating time, forage intake and weight changes of cattle
}

\author{
A. A. Ayantunde ${ }^{1,2}$, S. Fernández-Rivera ${ }^{1}$, P. H. Y. Hiernaux ${ }^{1}$, H. van Keulen ${ }^{3}$, H. M. J. Udo ${ }^{4}$ and \\ M. Chanono ${ }^{5}$ \\ ${ }^{1}$ International Livestock Research Institute (ILRI), ILRI/ICRISAT, B P 12404, Niamey, Niger \\ ${ }^{2}$ Institute for Animal Science and Health (ID-DLO), Department of Ruminant Nutrition, Runderweg 2, PO Box 65, \\ 8200 AB Lelystad, The Netherlands \\ ${ }^{3}$ Research Institute for Agrobiology and Soil Fertility (AB-DLO), PO Box 14, 6700 AA Wageningen, The Netherlands \\ ${ }^{4}$ Animal Production Systems Group, Wageningen Institute of Animal Sciences, PO Box 338, 6700 AH Wageningen, \\ The Netherlands \\ ${ }^{5}$ Ministére de l'Agriculture et l'Elevage, Centre du Multiplication de Betail, Toukounous, Niger
}

\begin{abstract}
Sixty-four Azawak male calves were used to study the effect of nocturnal grazing (NG) and supplementation (S) in the dry season on forage and water intake, faecal output, eating time and weight changes of cattle in the Sahel. Treatments were factorial combinations of four levels of $\mathrm{NG}(0,2,4$ and $6 \mathrm{~h} /$ day) and two levels of $S$ (0 and $608 \mathrm{~g}$ dry matter (DM) per animal per day). All animals were allowed to graze $10 \mathrm{~h}$ during the day and were weighed every 2 weeks during the 70-day experimental period. Eight oesophageally fistulated steers were used in a cross-over design to sample the diet (forage) selected during the day and at night by supplemented and non-supplemented animals. Extrusa crude protein and in vitro organic matter digestibility were not influenced by supplementation (P > 0.05). Time spent eating during the day or at night were not affected by supplementation but total eating time increased by 39.4 (s.e. 2.1) $\mathrm{min} / \mathrm{h}$ of NG. Forage intake increased with increase in NG, while total food intake (forage + supplement) increased with supplementation (82.4 v. 92.1 (s.e. 2.4) g DM per $\mathrm{kg} \mathrm{M}^{0.75}$ per day). The supplemented animals also drank more water than the non-supplemented (26.2 v. 24.81 per animal per day). Average live-weight change (LWC) increased by 24.4 (s.e. 8.7) and 9.3 (s.e. 6.2) $\mathrm{g} / \mathrm{h}$ of NG in non-supplemented and supplemented animals, respectively. Supplementation improved LWC (-107 v. 99 g/day, s.e. 14, P < 0.05). Night grazing improves dry season performance and its effect decreases when cattle are supplemented.
\end{abstract}

Keywords: cattle, feeding behaviour, food intake, noctural activity, supplementary feeding.

\section{Introduction}

Nocturnal grazing and night-time corralling of cattle are alternative herd management practices in the west African Sahel (Dicko-Touré, 1980; FernándezRivera et al., 1995; Powell et al., 1996). Results from previous studies (Fernández-Rivera et al., 1996; Ayantunde, 1998) demonstrated that when cattle are corralled (i.e. no night grazing) at night during the dry season to collect manure, forage intake decreased, and weight losses increased. Therefore, night corralling increased the need for supplementation. On the other hand, night grazing improved animal performance (King, 1983; Khombe et al., 1992) but it reduced the amount of collectable manure for cropping (Ayantunde, 1998). In addressing this conflict of interest it is necessary to determine the interactions between night grazing and supplementation. The objective of this study was to determine the effect of night grazing and supplementation on diet selection, forage intake, faecal output, water intake, eating time and weight changes of cattle.

\section{Material and methods}

Study site

A grazing trial was carried out for 70 days in the late dry season between April and June 1997 at Toukounous, Niger $\left(14^{\circ} 30^{\prime} \mathrm{N}\right.$ and $\left.3^{\circ} 17^{\prime} \mathrm{E}\right)$. The paddock used was a fenced area of 75 ha. The soil was predominantly sandy while alluvial clay plain 
accounted for proportionately 0.06 of the paddock. The herbaceous vegetation of the paddock was dominated by annual grasses, i.e. Brachiara xantholeuca, Cenchrus biflorus, Schoenefeldia gracilis, forbs such as Indigofera senegalensis, Sesbania leptocarpa and Alysicarpus ovalifolius. Scattered shrubs and small trees including those having browse value, such as Maerua crassifolia, Acacia laeta and Salvadora persica, were found at an average density of 210 plants per ha (Achard and Chanono, 1995).

\section{Animals and treatments}

Sixty-four Azawak (Bos indicus) male calves with an average live weight of 224 (s.e. 7) kg were randomly allotted to eight treatments defined by a factorial combination of four different durations of night grazing $(0,2,4$ and $6 \mathrm{~h})$ and two levels of supplementation (0 and $608 \mathrm{~g}$ dry matter (DM) per day). Animals with $2 \mathrm{~h}$ duration grazed between 04:00 and 06:00 h, while those with 4 and $6 \mathrm{~h}$ durations grazed between 02:00 and 06:00 h, and 00:00 and 06:00 $\mathrm{h}$, respectively. All animals grazed for $10 \mathrm{~h}$ between 08:00 and 18:00 $\mathrm{h}$ during the day. All animals were ear-tagged for identification. In addition, cloth-band belts of six easily distinguishable colours (one per treatment) were attached to the neck of animals that grazed in the night. To facilitate easy identification, especially for observation of feeding behaviour in the night, the ear-tag number of each animal was written on the neck-belt with an indelible marker. The animals were herded by two herdsmen during the day and another two in the night. For easy removal of the animals for night grazing, the enclosure was partitioned into four sections with wire mesh and the animals were separated after returning from day grazing into each compartment according to their nocturnal grazing regimes. Back in the corral after day grazing at 18:00 $\mathrm{h}$, animals in the corresponding treatments were given supplement individually. The supplement used comprised 929, 59 and $12 \mathrm{~g} / \mathrm{kg}$ DM of millet bran, superphosphate and salt, respectively. The supplement had a crude protein (CP) content of $140 \mathrm{~g} / \mathrm{kg} \mathrm{DM}$, organic matter (OM) digestibility of $651 \mathrm{~g} / \mathrm{kg} \mathrm{DM}$ and metabolizable energy (ME) of $10.67 \mathrm{MJ} / \mathrm{kg}$ DM. The diet provided $85 \mathrm{~g} \mathrm{CP}$ and 6.5 MJ ME per day. The quantity of millet bran offered was calculated, using the Agricultural and Food Research Council (1993) maintenance requirement of grazing steers, to meet the daily energy deficit of about $6 \mathrm{MJ}$ of animals grazing natural pasture alone in the dry season at the same site.

\section{Diet selection}

Eight oesophageally fistulated steers fitted with removable cannulas were randomly divided into two groups and used in a cross-over design for sampling the diet selected during the day and at night. Both groups grazed in the day (08:00 to 18:00 h) and at night $(02: 00$ to $06: 00 \mathrm{~h})$. One group was given the supplement while the second group received no supplement. After 3 weeks of adaptation to the supplement and grazing regimes, samples of the forage selected (extrusa) were collected on 3 days consecutively for about $20 \mathrm{~min}$ at 09:00 and 15:00 h during the day grazing period, and at 03:00 and 05:00 $\mathrm{h}$ at night. The extrusa was collected in wire screen bottom bags. The supplementation of the two groups was then reversed and after 10 days of adaptation extrusa samples were collected for 3 days the same way. The extrusa samples were placed in a container with ice and kept frozen until they were processed. The samples were dried at $55^{\circ} \mathrm{C}$ and ground to pass a $1-\mathrm{mm}$ screen. They were analysed for $\mathrm{DM}$ and $\mathrm{OM}$ and nitrogen $(\mathrm{CP}=\mathrm{N} \times 6.25)$. Organic matter digestibility (OMD) was determined by the in vitro gas production technique calibrated with standards obtained in vivo (Menke et al., 1979).

\section{Faecal output}

In May 1997, the 64 male calves were fitted with canvas faecal collection bags for total collection. Faeces were collected for 9 days, after an accustomization period of 7 days. The bags of all animals were emptied at the start and end of the day grazing period. At each collection the fresh faeces from each animal were weighed and a $0 \cdot 1$ proportional sample taken and sun-dried. The sundried morning and evening samples were then weighed, bulked per animal, pounded, mixed and sub-sampled. The sub-samples were ground to pass a $1 \mathrm{~mm}$ screen and the contents of DM, OM, nitrogen (N) and phosphorus (P) determined (Cook and Stubbendieck, 1986).

\section{Collectable manure}

Collectable manure is defined as the amount of faeces excreted while in the corral. The calculation of amounts of collectable manure was based on the faecal collection described in the previous section. For animals that did not graze at night, collectable manure was the amount of faeces excreted in the corral between 18:00 and 08:00 h, i.e. the faeces collected in the bags at 08:00 h. For animals that grazed at night, collectable manure was estimated by subtracting from the faeces produced during the night the faecal output during nocturnal grazing. Faecal output during night grazing was not measured but was calculated as the product of faecal excretion rate per hour during the diurnal grazing and the number of hours of nocturnal grazing. The diurnal rate of excretion was calculated separately for supplemented and non-supplemented animals. 
The total faecal $\mathrm{N}$ and $\mathrm{P}$ collected was calculated as the product of estimated collectable manure and the concentration of $\mathrm{N}$ and $\mathrm{P}(\mathrm{g} / \mathrm{kg} \mathrm{DM})$ in the faeces. Two assumptions were made in this method of calculation of collectable manure. The first was that the excretion rate during grazing in the night was the same as in the day. This assumption was based on results from previous studies (Ayantunde, 1998) which indicated that the difference in excretion rate of faecal DM between cattle allowed to graze only at night and those that grazed only during the day was not significant. The second assumption was that the excretion rate during the period in the corral was different from that during grazing at night. This was in line with the observation by Fernández-Rivera et al. (1995) that the rate of defecation (g of faecal DM excreted per $h$ ) during the period in the corral time was lower than that during grazing.

\section{Measurements}

The amount of supplement given and its digestibility were used to calculate the amount of faeces generated from the consumption of supplement. Faecal output attributed to supplement was subtracted from total faecal output to determine faecal output from forage. Forage intake was then determined from these individual estimates of faecal output from forage, and from the means of in vitro OMD of the extrusa of the diet selected in each treatment. It was assumed that the supplement had no effect on the digestibility of the forage. The in vitro OMD for each treatment was calculated as a function of the number of hours grazed at night, since significant differences in diet composition between day and night were observed. Animals were weighed every 2 weeks on 3 days consecutively. Average live-weight change (LWC) was estimated by regression of individual live weight on time. Water intake of the animals was measured daily during the data collection period in May. Each animal had access to water in two 251 graduated metallic buckets for $30 \mathrm{~min}$ in the morning before going out to graze. The activities of the animals, while at pasture, were recorded in May 1997. Four steers were randomly selected per treatment and the activities, classified as eating (defined as prehension, mastication and searching for food), resting and walking were recorded every $5 \mathrm{~min}$ for eight days by eight observers. In the night, observations were aided by a lamp.

\section{Statistical analyses}

Because the treatments were not replicated and social facilitation occurs in groups of grazing animals, regression analysis based on the treatment means was used to analyse the intakes. Regression analysis was used to evaluate the responses of eating time, forage intake, faecal output, collectable manure, water intake and average LWC to night grazing time $(0,2,4$ and $6 \mathrm{~h})$ at two levels of supplementation using the group means for eight animals (i.e. no. $=8$ ). The significant quadratic effect of night grazing (NG) was included in the model for eating time. Data for eating time, faecal output, collectable manure, water intake and average live weight change were analysed using analysis of variance with a factorial treatment structure according to the ANOVA procedure in Statistical Analysis Systems Institute (SAS, 1987). The model for analysis of water intake included live weight of the animals in addition to the factors studied while the initial live weight was included in the model for LWC. Extrusa variables were analysed using a balanced multi-way analysis of variance to examine the effects of period of collection, level of supplement (S), time of collection $(\mathrm{T})$, and their interactions $(\mathrm{S} \times \mathrm{T})$. Contrasts were used to compare quality of diets selected during day (09:00 and 15:00 $\mathrm{h}$ ) and night (03:00 and 05:00 h). Unless it is specified differently, the level of significance was declared at $P<0.05$. All data were analysed using SAS (1987).

\section{Results}

\section{Diet quality}

Extrusa CP (non-supplemented v. supplemented; 64 v. (s.e. 3) $68 \mathrm{~g} / \mathrm{kg}$ DM) and in vitro organic matter digestibility (518 v. 509 (s.e. 11) $\mathrm{g} / \mathrm{kg} \mathrm{DM}$ ) were not

Table 1 Composition of extrusa ( $\mathrm{g} / \mathrm{kg}$ dry matter) selected by oesophageally fistulated steers at different collection times (h) with or without supplement

\begin{tabular}{|c|c|c|c|c|c|c|c|c|c|}
\hline \multirow[b]{2}{*}{ Component } & \multicolumn{4}{|c|}{ Without supplement } & \multicolumn{4}{|c|}{ With supplement } & \multirow[b]{2}{*}{ s.e. } \\
\hline & 09:00 & $15: 00$ & 03:00 & 05:00 & 09:00 & $15: 00$ & 03:00 & 05:00 & \\
\hline Organic matter & 841 & 848 & 848 & 843 & 854 & 851 & 856 & 840 & 4 \\
\hline Crude protein & $76^{\mathrm{a}}$ & $68^{a}$ & $55^{\mathrm{b}}$ & $57^{\mathrm{b}}$ & $79^{\mathrm{a}}$ & $76^{\mathrm{a}}$ & $57^{\mathrm{b}}$ & $62^{\mathrm{b}}$ & 3 \\
\hline OMDt & $503^{a}$ & $490^{\mathrm{a}}$ & $545^{\mathrm{b}}$ & $533^{\mathrm{b}}$ & $468^{\mathrm{a}}$ & $488^{\mathrm{a}}$ & $539^{\mathrm{b}}$ & $541^{\mathrm{b}}$ & 12 \\
\hline DOM & $388^{\mathrm{a}}$ & $386^{\mathrm{a}}$ & $436^{\mathrm{b}}$ & $415^{\mathrm{b}}$ & $374^{\mathrm{a}}$ & $386^{\mathrm{a}}$ & $432^{\mathrm{b}}$ & $419^{b}$ & 11 \\
\hline
\end{tabular}

a,b Differing superscripts denote significant differences between means within rows $(P<0 \cdot 05)$.

$+\mathrm{OMD}=$ in vitro organic matter digestibility.

$\ddagger \mathrm{DOM}=$ digestible organic matter (OMD $\times$ organic matter). 


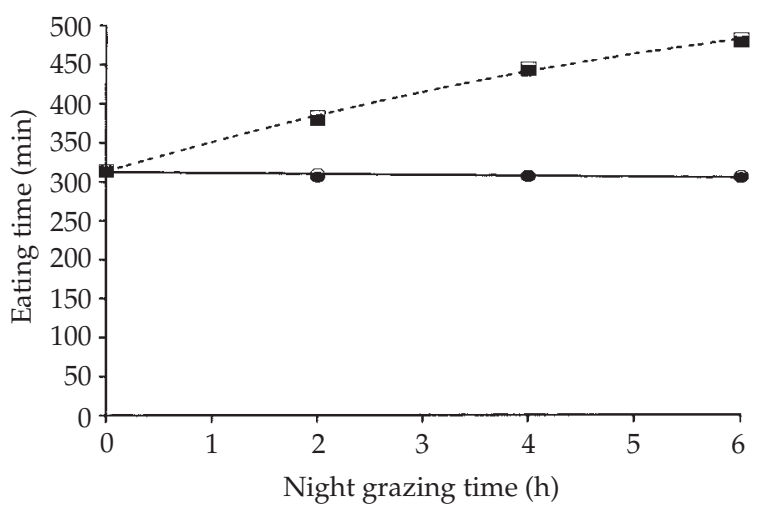

Figure 1 Actual time spent eating during the day $(\boldsymbol{0}, 0)$ (s.e. 2) and in total $(\boldsymbol{\square}, \square)$ (s.e. 3) by supplemented (solid symbols) and non-supplemented (open symbols) cattle grazing for different periods during the night.

influenced by supplementation (Table 1). However, $\mathrm{CP}$ content of the diet selected in the day was higher $(P<0.05)$ than that selected at night (day $v$. night: 75 v. (s.e. 2) $58 \mathrm{~g} / \mathrm{kg} \mathrm{DM}$ ), whereas the reverse was the case for in vitro OMD (487 v. 539 (s.e. 9) g/kg DM).

\section{Time spent eating}

Time spent eating (min/day) was not affected by supplementation (Figure 1) with means during the day of 310 v. 307 (s.e. 2), at night of 97 v. 96 (s.e. 1), and in total 407 v. 403 (s.e. 2) for the nonsupplemented $v$. supplemented animals, respectively. Time spent eating during the day decreased as night grazing time increased. Cattle with no night grazing spent $314 \mathrm{~min}$ eating during the day, while those with 2, 4 and $6 \mathrm{~h}$ of NG spent 308, 307 and $305 \mathrm{~min}$, respectively. The relationships between eating time (min/day) during the day, at night, and in total, and the night grazing time allowed (NG, h) are described by the following equations which only include parameters significant at $P<0.05$ :

day eating time $=312 \cdot 70$ (s.e. $1 \cdot 89)$

$$
-1.43 \text { (s.e. } 0.47) \mathrm{NG}
$$$$
\left(R^{2}=0.84, P<0 \cdot 05\right)
$$

night eating time $=42.73($ s.e. $1 \cdot 14) \mathrm{NG}$

$$
\begin{gathered}
-2 \cdot 22 \text { (s.e. } 0.16) \mathrm{NG}^{2} \\
\left(R^{2}=0.99, P<0.01\right)
\end{gathered}
$$

total eating time $=313 \cdot 24($ s.e. $2 \cdot 64)+39 \cdot 37$ (s.e. $2 \cdot 12)$

$\mathrm{NG}-1.90$ (s.e. $0 \cdot 33) \mathrm{NG}^{2}$

$\left(R^{2}=0.99, P<0.01\right)$

\section{Faecal output}

There was no difference in faecal output from forage between non-supplemented and supplemented animals (44.3 v. 43.7 (s.e. 1.1) g DM per kg $\mathrm{M}^{0.75}$ per day; Table 2). However, supplemented cattle had higher $(P<0.05)$ total faecal output than nonsupplemented animals (47.8 v. 44.3 (s.e. 1.2) g DM per $\mathrm{kg} \mathrm{M}^{0.75}$ per day). Daily faecal output from the forage increased, though not significantly, with increased night grazing time $(0 \mathrm{~h}=42 \cdot 3,2 \mathrm{~h}=42 \cdot 6$, $4 \mathrm{~h}=45 \cdot 4$, and $6 \mathrm{~h}=45 \cdot 6$ (s.e. $1 \cdot 1) \mathrm{g} \mathrm{DM}$ per $\mathrm{kg} \mathrm{M}^{0.75}$ ). Supplementation had no effect on the concentration of nitrogen in faeces with means of 13.3 and $13.0 \mathrm{~g} \mathrm{~N}$ per $\mathrm{kg} \mathrm{DM}$ in faeces voided by non-supplemented and supplemented animals, respectively. Phosphorus concentration in faeces excreted by supplemented animals was higher than that in non-supplemented animals $(2 \cdot 5$ v. $1 \cdot 8$ (s.e. $0 \cdot 1) \mathrm{g} / \mathrm{kg} \mathrm{DM})$.

\section{Collectable manure}

There was no difference in daily collectable manure between the supplemented and non-supplemented

Table 2 Daily total faecal output and faecal output from forage ( $g$ dry matter (DM) per $\left.\mathrm{kg} \mathrm{M}^{0.75}\right)$, concentration ( $\mathrm{g} / \mathrm{kg}$ DM) of nitrogen

\begin{tabular}{|c|c|c|c|c|c|c|c|c|c|c|}
\hline \multirow[b]{3}{*}{ Supplement (g DM per day) } & \multicolumn{8}{|c|}{ Night grazing time $(\mathrm{h})$} & \multirow[b]{3}{*}{ s.e. } & \multirow[b]{3}{*}{ Significance } \\
\hline & \multicolumn{2}{|c|}{0} & \multicolumn{2}{|c|}{2} & \multicolumn{2}{|c|}{4} & \multicolumn{2}{|c|}{6} & & \\
\hline & 0 & 608 & 0 & 608 & 0 & 608 & 0 & 608 & & \\
\hline Total & $41 \cdot 6$ & $47 \cdot 2$ & $42 \cdot 2$ & $47 \cdot 1$ & $46 \cdot 1$ & $48 \cdot 7$ & $47 \cdot 1$ & $48 \cdot 3$ & $1 \cdot 2$ & $S^{*}$ \\
\hline Output from forage & $41 \cdot 6$ & $43 \cdot 1$ & $42 \cdot 2$ & $43 \cdot 0$ & $46 \cdot 1$ & $44 \cdot 6$ & $47 \cdot 1$ & $44 \cdot 2$ & $1 \cdot 1$ & \\
\hline $\mathrm{N}$ concentration in faeces & $13 \cdot 7$ & $13 \cdot 6$ & $12 \cdot 9$ & $13 \cdot 3$ & $14 \cdot 8$ & $12 \cdot 8$ & $11 \cdot 8$ & $12 \cdot 5$ & $0 \cdot 3$ & \\
\hline P concentration in faeces & $1 \cdot 9$ & $2 \cdot 6$ & $1 \cdot 7$ & $2 \cdot 6$ & $1 \cdot 8$ & $2 \cdot 4$ & 1.7 & $2 \cdot 5$ & $0 \cdot 1$ & $S^{* * *}$ \\
\hline Collectable DM & 1085 & 1283 & 965 & 996 & 689 & 764 & 489 & 505 & 100 & $\mathrm{NG}^{*}$ \\
\hline Collectable N & 14.9 & $17 \cdot 4$ & $12 \cdot 4$ & $13 \cdot 2$ & $10 \cdot 2$ & 9.8 & $5 \cdot 8$ & $6 \cdot 3$ & 1.4 & $\mathrm{NG}^{* *}$ \\
\hline Collectable P & $2 \cdot 1$ & $3 \cdot 3$ & $1 \cdot 6$ & $2 \cdot 6$ & $1 \cdot 2$ & $1 \cdot 8$ & $0 \cdot 8$ & $1 \cdot 3$ & $0 \cdot 2$ & $\mathrm{NG}^{*}, \mathrm{~S}^{* * *}$ \\
\hline
\end{tabular}
$(N)$ and phosphorus $(P)$ in faeces, and daily amounts ( $g$ per animal) of collectable faecal DM, $N$ and $P$ of supplemented and nonsupplemented cattle grazing for different periods during the night

$+\mathrm{NG}=$ linear effect of night grazing; $\mathrm{S}=$ linear effect of supplementation. 
animals (887 v. 807 (s.e. 5) g DM per animal; Table 2). The phosphorus concentration in the collectable manure from supplemented cattle was significantly higher than in the animals that were not supplemented $(2.6$ v. 1.4 (s.e. $0 \cdot 1) \mathrm{g} / \mathrm{kg} \mathrm{DM})$. The daily amount of collectable manure decreased significantly by $2.2 \mathrm{~g}$ DM per $\mathrm{kg} \mathrm{M} \mathrm{M}^{0.75}$ per h of night grazing. Night grazing also reduced $(P<0 \cdot 05)$ the amount of faecal $\mathrm{N}$ and $\mathrm{P}$ that could be collected for manuring.

\section{Forage intake}

The relationship between total daily food intake (forage + supplement, g DM per $\mathrm{kg} \mathrm{M}^{0.75}$ ), night grazing time (NG, h) and supplementation (, $\mathrm{kg}$ DM per day) is described by equation 4 . Daily forage intake by non-supplemented cattle was $75.9,78.1$, 86.4 and $89.1 \mathrm{~g} \mathrm{DM}$ per $\mathrm{kg} \mathrm{M}^{0.75}$ for $0,2,4$ and $6 \mathrm{~h}$ of night grazing, respectively, and by supplemented animals was $78.6,79.7,83.5$ and $83.5 \mathrm{~g}$ DM per $\mathrm{kg}$ $\mathrm{M}^{0.75}$. Total daily food intake increased with supplement feeding (non-supplemented $v$. supplemented: 82.4 v. $92 \cdot 1 \mathrm{~g}$ DM per $\mathrm{kg} \mathrm{M}^{0.75}$ ). Regression analysis (equation 5) showed that ingestion rate (g DM per min of eating time) was not affected $(P>0.05)$ by level of supplement (11.2 $v$. $11.4 \mathrm{~g}$ DM per min) but decreased linearly with increase in night grazing time:

$$
\begin{gathered}
\text { total food intake }=75.21+2.39 \mathrm{NG}+13.99 \mathrm{~S} \\
-1.44 \mathrm{NG} \times \mathrm{S} \\
\left(R^{2}=0.97, P<0.05\right)
\end{gathered}
$$

ingestion rate $=13.18-0.62 \mathrm{NG}$

$$
\left(R^{2}=0.53, P<0 \cdot 01\right)
$$

\section{Water intake}

Supplemented animals consumed more $(P<0 \cdot 05)$ water than those not supplemented (26.2 v. 24.81 per animal per day). Night grazing time did not affect water intake with daily means of $24 \cdot 5,26 \cdot 1,24 \cdot 6$, and 26.31 per animal (s.e. 0.4; Table 3) for 0, 2, 4 and $6 \mathrm{~h}$ of night grazing, respectively. Regression analysis of daily water intake (l) showed that $94 \mathrm{ml}$ of water was consumed daily per $\mathrm{kg}$ live weight (LW), $60 \mathrm{ml}$ per $\mathrm{g}$ DM per $\mathrm{kg} \mathrm{M}^{0.75}$ of forage intake, $136 \mathrm{ml}$ per $\mathrm{g} \mathrm{DM}$ per $\mathrm{kg} \mathrm{M}^{0.75}$ of supplement intake (SI):

$$
\begin{gathered}
\text { water intake }=0.09(\text { s.e. } 0.02) \mathrm{LW} \\
+0.06 \text { (s.e. } 0.03) \mathrm{FI}+0 \cdot 14(\text { s.e. } 0.05) \mathrm{SI} \\
\left(R^{2}=0.86, P<0.05\right)
\end{gathered}
$$

\section{Weight changes}

Average LWC for non-supplemented cattle (s.e. 27) was $-191,-123,-64$, and $-49 \mathrm{~g} /$ day for $0,2,4$ and $6 \mathrm{~h}$ of night grazing, respectively, and in supplemented animals was 59, 99, 127 and $111 \mathrm{~g} /$ day. In non-supplemented animals, LWC increased by $24 \cdot 4$ (s.e. 8.7 ) $\mathrm{g} / \mathrm{h}$ of $\mathrm{NG}$, and in those that were supplemented by 9.3 (s.e. 6.2) $\mathrm{g} / \mathrm{h}$. The response in LWC in supplemented animals tended to decrease with more than $4 \mathrm{~h}$ of NG. Supplementation improved LWC (-107 v. $99 \mathrm{~g} /$ day, s.e. $14, P<0.05)$. The regression analysis of LWC (g/day) on NG (h), S ( $\mathrm{kg} \mathrm{DM} /$ day), NG $\times \mathrm{S}$ with initial live weight (INWT, $\mathrm{kg}$ ) as a covariate is shown in equation 7 :

$$
\begin{gathered}
\text { LWC }=-43.81(\text { s.e. } 43.80)-0.68 \text { (s.e. } 0.16) \mathrm{INWT} \\
+24.43(\text { s.e. } 6.08) \mathrm{NG}+251.93(\text { s.e. } 31 \cdot 38) \mathrm{S} \\
-15 \cdot 17(\text { s.e. } 7.98) \mathrm{NG} \times \mathrm{S} \\
\left(R^{2}=0.74, P<0.05\right)
\end{gathered}
$$

\section{Discussion}

In this study supplementation with millet bran and superphosphate did not significantly affect the quality of forage selected from range. Khombe et al. (1992) and Schlecht (1995) reported similar results when feeding energy rich supplements to

\begin{tabular}{|c|c|c|c|c|c|c|c|c|c|c|}
\hline \multirow[b]{3}{*}{ Supplement (g DM per day) } & \multicolumn{8}{|c|}{ Night grazing time (h) } & \multirow[b]{3}{*}{ s.e. } & \multirow[b]{3}{*}{ Significancet } \\
\hline & \multicolumn{2}{|c|}{0} & \multicolumn{2}{|c|}{2} & \multicolumn{2}{|c|}{4} & \multicolumn{2}{|c|}{6} & & \\
\hline & 0 & 608 & 0 & 608 & 0 & 608 & 0 & 608 & & \\
\hline (l per animal) & $23 \cdot 7$ & $26 \cdot 3$ & $24 \cdot 9$ & $27 \cdot 3$ & $24 \cdot 7$ & $24 \cdot 4$ & $25 \cdot 8$ & $26 \cdot 8$ & $0 \cdot 4$ & $S^{*}$ \\
\hline (l/kg forage DM) & $5 \cdot 7$ & $5 \cdot 4$ & $5 \cdot 6$ & $5 \cdot 5$ & $5 \cdot 3$ & $4 \cdot 7$ & $5 \cdot 5$ & $5 \cdot 2$ & $0 \cdot 1$ & \\
\hline
\end{tabular}
oesophageally fistulated steers. The higher $\mathrm{CP}$ and lower digestibility in the diet selected in the day compared with that selected at night may be due to increased ingestion of woody forage and/or legumes, which are higher in $\mathrm{CP}$ but are less digestible than grasses during most of the dry season (Ayantunde et al., 1999). Ickowicz (1995) reported that woody forage may contribute proportionately 0.22 to 0.64 of the $\mathrm{CP}$ ingested by cattle grazing

Table 3 Daily water intake by supplemented and non-supplemented cattle grazing for different periods during the night

$+\mathrm{S}=$ linear effect of supplementation. 
Sahelian rangelands in the late dry season. This contrasts with results of our previous studies (Fernández-Rivera et al., 1996; Ayantunde, 1998), in which no difference in the quality of diet selected during the day and at night was found. The difference in response may be associated with differences in both the grazing site and experimental design used.

The absence of an effect of supplementation on eating time in the day or at night may be due to the level and type of supplement given. It may have been affected also by social facilitation (Vallentine, 1990) occurring in this experiment, where cattle on the different treatments grazed the same paddock. The ingestion rate of $13.18 \mathrm{~g}$ DM per min of eating time observed in animals that grazed only during the day in this study was similar to that reported by Fall et al. (1997) for non-working oxen with access to forage only in the day. The linear decline in eating rate as duration of grazing increased, is consistent with the observation of Smith (1961) that cattle with restricted grazing time ate faster than those that were not restricted.

The substitution coefficient of supplement, observed in this study, was zero in the absence of night grazing and low $(6 \%)$ when night grazing was allowed. This indicates additivity between forage and supplement given. Consequently, total intake of forage and supplement by supplemented calves increased by almost the same amount as the quantity of supplement given. Similar responses to feeding an energy rich supplement were found by Minson (1990) when available forage was low or of poor quality. Schlecht (1995) obtained similar results in Mali when feeding 1.2 to $1.5 \mathrm{~kg}$ DM per day of a mixture of rice-feed meal and cotton-seed expeller $(4: 1)$ to steers grazing during the day in the dry season. Forage intake by cattle has also been reported to be unaffected by protein supplementation in the winter by Judkins et al. (1985) and Villalobos et al. (1997). However, forage intake was depressed by half when a mixture of rice-feed meal and cotton-seed expeller $(5: 1)$ were given at $2.5 \mathrm{~kg} \mathrm{DM}$ per animal per day to the grazing steers in Mali (Schlecht, 1995). Animals that were not supplemented increased their forage intake as night grazing time increased. This reaffirms the observation of King (1983) and Fernández-Rivera et al. (1996) that additional grazing time in the night leads to increased forage consumption by cattle.

A non-significant difference in faecal output associated with forage between supplemented and non-supplemented animals was also found by Schlecht (1995). The range of values found in this study for total faecal output is similar to that by Dicko-Touré (1980) in Mali. The higher concentration of $\mathrm{P}$ in faeces excreted by the supplemented animals can be attributed to supplementary feeding of $\mathrm{P}$ in the form of superphosphate and the phosphorus in the millet bran (about $0.60 \%$ in DM). Since the principal pathway for the excretion of $\mathrm{P}$ is in the faeces, more $\mathrm{P}$ is expected to be excreted with a higher concentration in the diet. These results suggest that in extensive systems such as those in the Sahel, a substantial part of the $\mathrm{P}$ given to animals that are corralled overnight for manure collection could be recovered in the cropped land and used to sustain crop production.

More faecal DM, N, and P could be collected for manuring crop fields from animals that did not graze during the night. These results agree with the previous finding (Ayantunde, 1998) that the amount of collectable manure declines with increase in duration of night grazing. However, the reverse may be the case when night grazing occurs on croplands as faecal deposition during this period is for manuring crop fields. The results also reaffirm the influence of animal management on amounts of manure available for cropping (Powell et al., 1996). The non-significant effect of supplementation on collectable manure may be due to the level and type of supplement used.

The significant effect of supplementation on water intake may be attributed to higher total food intake (forage + supplement) by the supplemented animals, as water intake is positively related to food intake. Sodium chloride and protein in the supplement can also lead to increased water intake as observed by King (1983) as more water is needed for salt and urea excretion. The ratio of water consumed and forage intake observed in this study was similar to the value of $4.51 / \mathrm{kg}$ forage DM intake reported by King (1983).

The experiment demonstrated that with supplementation cattle can maintain their live weight in the dry season in the Sahel. Better performance when giving energy rich supplements has also been reported in the region by Calvet $e t$ al. (1976), Khombe et al. (1992) and Schlecht (1995). These results suggest that the response to supplementary feeding is stronger when available forage quantity and quality are low (Minson, 1990). Increasing night grazing time was associated with lower weight loss in the non-supplemented group, but did not prevent weight loss even when $6 \mathrm{~h}$ grazing was allowed. The response to supplementation tended to decrease as night grazing time increased. The opposite is also true i.e. response 
to night grazing was lower in supplemented than in non-supplemented animals. Thus, when animals are denied night grazing in the dry season through night corralling, which is a common practice in west African Sahel, supplementation is necessary to achieve good performance. A major constraint to the practice is however, cost, as supplementary feeding is often expensive and it is doubtful if the advantage of supplementary feeding in the late dry season can be maintained during the following wet season (Schlecht, 1995).

\section{Conclusion}

This study shows that energy supplementation has no effect on the quality of the forage selected in the day or at night. It also demonstrates that when animals are denied night grazing when they are corralled at night, supplementation is necessary to maintain good performance in the dry season. Although supplementation is justified to maintain animal performance, economic considerations will determine its viability in practice. The economic consequences, in terms of both livestock output and increased crop yield, of using this method of manuring crop fields need to be considered when choosing between night grazing and night corralling.

\section{Acknowledgements}

The authors thank the staff of Station Sahelienne Expérimentale de Toukounous, Niger, for their support during the field work. We also wish to thank Harouna Garba for animal management and Mamadou Koukou for laboratory analyses of extrusa samples. The advice of Wiebe Koops on statistical analysis is highly appreciated. Thanks are also due to the referees for their comments on the improvement of the manuscript.

\section{References}

Achard, F. and Chanono, M. 1995. [Animal performance of a livestock production system in Toukounous in the Sahelian Niger.] Sécheresse 6: 215-222.

Agricultural and Food Research Council. 1993. Energy and protein requirements of ruminants. An advisory manual prepared by the AFRC Technical Committee on Responses to Nutrients. CAB International, Wallingford, UK.

Ayantunde, A. A. 1998. Influence of grazing regimes on cattle nutrition and performance and vegetation dynamics in Sahelian rangelands. Ph.D. thesis, Wageningen Agricultural University.

Ayantunde, A. A., Hiernaux, P., Fernández-Rivera, S., van Keulen, H. and Udo, H. M. J. 1999. Selective grazing by cattle on spatially and seasonally heterogeneous rangeland in Sahel. Journal of Arid Environments 42: 261-279.

Calvet, H., Friot, D. and Gueye, I. S. 1976. [Minerals supplementation, nutrition and weight changes in Sahelian zebu cattle in the dry season.] Revue d'Élevage et de Médecine Vétérinaire des Pays Tropicaux 29: 59-66.
Cook, C. W. and Stubbendieck, J. 1986. Range research: basic problems and techniques. Society for Range Management, Denver, CO.

Dicko-Touré, M. S. 1980. The contribution of browse to cattle fodder in the sedentary system of the Office du Niger. In Browse in Africa: the current state of knowledge (ed. H. N. Le Houérou), pp. 313-319. International Livestock Center for Africa, Addis Ababa.

Fall, A., Pearson, R. A., Lawrence, P. R. and Fernández-Rivera, S. 1997. Nutrition of draught oxen in semi-arid west Africa. 2. Effect of work on intake, apparent digestibility and rate of passage of food through the gastro-intestinal tract in draught oxen given crop residues. Animal Science 64: 217-225.

Fernández-Rivera, S., Ayantunde, A., Hiernaux, P. H. Y. and Turner, M. 1996. Nocturnal grazing effects on the nutrition of cattle. Journal of Animal Science 74: (suppl. 1) 200 (abstr.).

Fernández-Rivera, S., Williams, T. O., Hiernaux, P. and Powell, J. M. 1995. Faecal excretion by ruminants and manure availability for crop production in semi-arid West Africa. In Livestock and sustainable nutrient cycling in mixed farming systems of sub-Saharan Africa, volume II: technical papers (ed. J. M. Powell, S. Fernández-Rivera, T. O. Williams and C. Renard), pp. 149-169. International Livestock Centre for Africa, Addis Ababa.

Ickowicz, A. 1995. [Assessing the vegetation dynamics in pastoral production systems in the Sahelian Chad.] Thése d'Université, Paris XII-Créteil.

Judkins, M. B., Krysl, L. J., Wallace, J. D., Galyean, M. L., Jones, K. D. and Parker, E. E. 1985. Intake and diet selection by protein supplemented grazing steers. Journal of Range Management 38: 210-214.

Khombe, C. T., Dube, I. A. and Nyathi, P. 1992. The effects of kraaling and stover supplementation during the dry season on body weight and manure production of Mashona steers in Zimbabwe. African Livestock Research 1: 18-23.

King, J. M. 1983. Livestock water needs in pastoral Africa in relation to climate and forage. International Livestock Centre for Africa report no. 7. International Livestock Centre for Africa, Addis Ababa.

Menke, K. H., Raab, L., Salewski, A., Steingass, H. and Schneider, W. 1979. The estimation of the digestibility and metabolizable energy content of ruminant feeding stuffs from gas production when they are incubated with rumen liquor in vitro. Journal of Agricultural Science, Cambridge 93: 217-222.

Minson, D. J. 1990. Forage in ruminant nutrition. Academic Press Inc., San Diego, CA.

Powell, J. M., Fernández-Rivera, S., Hiernaux, P. and Turner, M. D. 1996. Nutrient cycling in integrated rangeland/cropland systems of the Sahel. Agricultural Systems 52: 143-170.

Schlecht, E. 1995. The influence of different levels of supplementation on feed intake and nutrient retention of zebu cattle in Sahelian agro-pastoral systems. Ph.D. thesis, University of Hohenheim.

Smith, C. A. 1961. Studies on the Northern Rhodesia Hyparrhenia veld. III. The effect on growth and grazing behaviour of indigenous cattle of restricting their daily 
grazing times by night kraaling. Journal of Agricultural Science, Cambridge 56: 243-248.

Statistical Analysis Systems Institute. 1987. SAS/STAT for personal computers. Statistical Analysis Systems Institute, Cary, NC.

Vallentine, J. F. 1990. Grazing management. Academic Press, San Diego, CA.
Villalobos, G., Adams, D. C., Klopfenstein, T. J., Nichols, J. T. and Lamb, J. B. 1997. Grass hay as a supplement for grazing cattle. I. Animal performance. Journal of Range Management 50: 351-356.

(Received 26 July 1999-Accepted 29 March 2000) 